\title{
STABILITY AND RHEOLOGICAL PROPERTIES OF ICE CREAMS PRODUCED WITH DAIRY BY-PRODUCTS
}

\author{
Roberta Barbosa de Meneses ${ }^{1,2}$, Adejanildo da Silva Pereira ${ }^{2}$, Thiago Oliveira Marinho ${ }^{3}$, Alex \\ Rodrigues de Andrare ${ }^{4}$, Hellen Cristina de Moura Guilherme ${ }^{4}$, Leonardo Fonseca Maciel ${ }^{5}$, \\ Maria Helena Miguez da Rocha-Leão ${ }^{4}$, Carlos Adam Conte-Junior ${ }^{2,6} \bowtie$ \\ ${ }^{1}$ Instituto Federal de Educação, Ciência e Tecnologia de Alagoas, Alagoas, Brazil. \\ ${ }^{2}$ Instituto de Química, Universidade Federal do Rio de Janeiro, Rio de Janeiro, Brazil. \\ ${ }^{3}$ Programa de Engenharia Química, Universidade Federal do Rio de Janeiro, Rio de Janeiro, Brazil. \\ ${ }^{4}$ Escola de Química, Universidade Federal do Rio de Janeiro, Rio de Janeiro, Brazil. \\ ${ }^{5}$ Faculdade de Farmácia, Universidade Federal da Bahia, Salvador, Brazil. \\ ${ }^{6}$ Faculdade de Veterinária, Universidade Federal Fluminense, Niterói, Brazil.

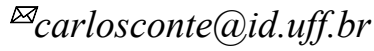 \\ https://doi.org/10.34302/crpjfst/2020.12.3.15 \\ Article history: \\ Received: \\ 28 April 2019 \\ Accepted: \\ 5 April 2020 \\ Keywords: \\ Dairy by-products; \\ Pollution; \\ Reutilization; \\ Ice cream; \\ Stability.

\section{ABSTRACT} \\ The majority of dairy industries (cheese, butter, ricotta, etc.) discard their \\ by-products in the environment causing intense pollution due to the high \\ concentration of organic matter in these products. An interesting solution \\ would be the reuse of these by-products in foods, such as ice cream. \\ However, unpleasant changes in this emulsion may occur, such as \\ undesirable phase separation. In this context, the aim of this work was to \\ observe the effects of the application of dairy wheys on ice cream's \\ rheological properties and stability. Ice cream formulations differed by \\ flavor (cream and chocolate), by type (milk, cheese whey, ricotta whey and \\ butter whey), and by proportions of wheys (0, 25, 50, 75 and 100\%). A \\ commercial sample was also evaluated as a comparison. The evaluated \\ parameters were zeta potential (ZP), particle size (PS), rheological behavior, \\ desorption, and concentration of $\mathrm{Ca}+\mathrm{Mg}$. The results showed that the \\ addition of whey, regardless of flavor and origin, reduced the viscosity and \\ increased PS and desorption, but did not compromise the ZP of most of the \\ samples (78.57\%). This behavior was concentration-dependent. The $\mathrm{Ca}+\mathrm{Mg}$ \\ content of the wheys and the flavorings had no influence on the desorption \\ index. Thus, the analyses revealed that different dairy by-products in ice \\ creams could be used without significantly compromising important quality \\ parameters and, at the same time, help to preserve the environment. \\ However, further experiments should be conducted (e.g. sensory analysis) \\ in order to better understand the technological potential of dairy by-products \\ application in ice creams.
}

\section{Introduction}

Dairy producers are one of the food industry's examples that produce large quantities of effluent with high organic load, i.e. high Chemical (COD) and Biochemical Oxygen Demands (BOD). These by-products can impose serious challenges in local sewage treatment systems, representing a significant environmental impact when discarded without proper treatment (Janes et al., 2008; Silva, 2011). Among the alternatives that minimize environmental aggression, the partial or total replacement of powdered milk, eggs, fats, sugar, and even protein in the formulations of several other processed food has high added value, 
considering the nutritional e technological potential of these dairy effluents. In addition, these by-products are inexpensive and could help the economy of many companies while reducing raw material costs, and therefore lowering the cost of production (Singh et al., 2012; Božanić et al., 2014).

One of the most popular desserts in the world is the ice cream and its consumption has been constantly increasing over the years, mainly due to its sweet taste and soft texture. It is a product appreciated by people of all ages and at any time of the year, being considered a healthy and nutritious food, not only because of its high energy value, but also because of its high digestibility (Aboulfazli et al., 2015; Kumar et al., 2016, Makares et al., 2014, Vadiveloo et al., 2014).

The macromolecules present in ice creams (fats, proteins and complex carbohydrates) significantly contribute to the perception of texture and taste (Akesowan, 2009). Among the ice cream quality parameters, two of the most important are the viscosity and stability of its visual characteristics, which should not show any phase separation during and right after the melting (Tharp et al., 1998).

The formation and stability of dispersed colloidal systems as ice cream, depend on many factors such as protein content, salt concentration and ionic strength (Corredig et al., 2011, Tharp et al., 1998, Bodyfelt et al., 1988). Little is known regarding phase separation of ice cream blends, considering that investigations on their stability behavior focus mainly on the physicochemical characteristics and sensory qualities when new ingredients are added, thus leaving a gap in terms of understanding this mechanism (BahramParvar et al., 2008; Cheng et al., 2015).

Taking into consideration the pollutant potential of dairy by-products, the reuse of these wastes in human foods, as well as the possible modifications that they can cause in the composition and structure of food (desirably or not), the aim of this study was to evaluate the behavior of the addition of ricotta whey, cheese whey, and butter whey in rheological properties and ice cream stability.

\section{Materials and methods}

All procedures were carried out in three experimental replicates.

\subsection{Formulation and processing of ice creams}

The residues were obtained from the draining step of the production of rennet cheese, butter, and ricotta as liquid whey and then immediately cooled/frozen in cold chamber at $18 \pm 2{ }^{\circ} \mathrm{C}$. They were kindly provided from an agro-industry located at Federal Institute of Alagoas (IFAL), Campus Satuba, being transported frozen to the Laboratory of Biochemical Engineering of the School of Chemistry at Federal University of Rio de Janeiro (UFRJ) in a time not exceeding 12 hours.

Cream and Chocolate flavors were used in the production of ice creams with different ingredient proportions $(\% \mathrm{w} / \mathrm{w})$ (Table 1$)$, where the ingredients were purchased in a local market of Rio de Janeiro-RJ. Milk was replaced by different proportions of liquid/thawed residues and a control sample $(0 \%$ of whey/100\% of milk) was also made. A sample of a commercial brand with a high market share was acquired for comparison purposes with the developed ice cream.

The procedure to obtain the ice creams was done using a specific equipment to make the samples (Cuisinart ${ }^{\circledR}$ ice cream model, Ice 100 model), in which the basic unit operations of its processing were provided: homogenization of the ingredients (less emulsifier), pasteurization of the mixture, maturation, beating/freezing (emulsifier addition). The ice creams were transferred to plastic polypropylene recipients with a capacity of $250 \mathrm{~mL}$, then stored in a freezer with the temperature set at $-18 \pm 2^{\circ} \mathrm{C}$. 
Table 1. Ice cream formulations with different whey percentages $(\% \mathrm{w} / \mathrm{w})$.

\begin{tabular}{|c|c|c|c|c|c|c|c|c|c|c|}
\hline \multirow{2}{*}{$\begin{array}{c}\text { Ingredients } \\
(\%)\end{array}$} & \multicolumn{5}{|c|}{ Cream flavor } & \multicolumn{5}{|c|}{ Chocolate flavor } \\
\hline & $0 \%$ & $25 \%$ & $50 \%$ & $75 \%$ & $100 \%$ & $0 \%$ & $25 \%$ & $50 \%$ & $75 \%$ & $100 \%$ \\
\hline Whole Milk & 66.86 & 16.72 & 33.43 & 50.14 & --- & 58.14 & 43.61 & 29.07 & 14.53 & --- \\
\hline Ricotta whey or Cheese whey or Butter whey & --- & 50.14 & 33.43 & 16.72 & 66.86 & --- & 14.53 & 29.07 & 43.61 & 58.14 \\
\hline Refined sugar & 17.44 & 17.44 & 17.44 & 17.44 & 17.44 & 17.44 & 17.44 & 17.44 & 17.44 & 17.44 \\
\hline Cream milk & 11.63 & 11.63 & 11.63 & 11.63 & 11.63 & 11.63 & 11.63 & 11.63 & 11.63 & 11.63 \\
\hline Thickener and Stabilizer & 0.58 & 0.58 & 0.58 & 0.58 & 0.58 & 0.58 & 0.58 & 0.58 & 0.58 & 0.58 \\
\hline Emulsifier & 0.58 & 0.58 & 0.58 & 0.58 & 0.58 & 0.58 & 0.58 & 0.58 & 0.58 & 0.58 \\
\hline $100 \%$ cocoa powder & --- & --- & --- & --- & --- & 11.63 & 11.63 & 11.63 & 11.63 & 11.63 \\
\hline Cream flavoring & 2.91 & 2.91 & 2.91 & 2.91 & 2.91 & --- & --- & --- & --- & --- \\
\hline
\end{tabular}




\subsection{Particle size and Zeta Potential}

The mean particle size (PS) and zeta potential (ZP) of the ice cream mixes samples were determined using the Malvern Zetasizer Nano Series (Malvern Instruments, UK) at a constant temperature of $25{ }^{\circ} \mathrm{C}$. Measurements were performed with an approximately 1:10.000 sample dilution in deionized water (Aboulfazli et al., 2014; Aboulfazli et al., 2015).

\subsection{Rheological behavior}

Rheological tests were carried out in melted ice cream samples (Aboulfazli et al., 2014; Aboulfazli et al., 2015) with a rotational viscometer OFITE 900 (OFI Testing Equipment, EUA) equipped with a Couette coaxial cylinder geometry. The viscometer was coupled to a Julabo F25 ( $\mathrm{GmbH}$, Germany) refrigerated circulator and all measurements were performed at a constant temperature of $4.0^{\circ} \mathrm{C} \pm 0.1^{\circ} \mathrm{C}$. Apparent viscosity and shear stress were assessed by linearly increasing the shear rate from 1.7 to $1,021 \mathrm{~s}^{-1}$. Thus, the representative viscosity value of $50 \mathrm{~s}^{-1}$ (i.e., the shear rate equivalent to that performed by the mouth during chewing according to Bourne, 2002) was captured and compared to values found in the literature.

Rheological data were used to calculate the consistency index $(\mathrm{K})$ and flow behavior index (n) through power-law model, represented by Eq. 1 (Rossa et al., 2012). Viscosity curves were also obtained and discussed throughout the text.

$$
\begin{aligned}
& \sigma=\mathrm{K}(\gamma)^{\mathrm{n}} \quad \cdots \text { Eq. } 1 \\
& \sigma=\text { shear stress }(\mathrm{mPa}) \\
& \mathrm{K}=\text { consistency index }\left(\mathrm{mPa} \mathrm{s}^{\mathrm{n}}\right) \text {; } \\
& \gamma=\text { shear rate }\left(\mathrm{s}^{-1}\right) \\
& \mathrm{n}=\text { flow behavior index. }
\end{aligned}
$$

\subsection{Stability Analysis}

Stability analysis of ice creams was carried out according to their desorption as described by the methodology of Cheng et al. (2015) with some modifications. The melted samples were poured into $100 \mathrm{~mL}$ glass beakers, slightly sealed and resting for one week. In each day, it was observed the presence of phase separation and the volume of the serum fraction formed in each sample was registered. The desorption index (DI) was determined by plotting the volumes recorded versus time, and the percentage of desorption was determined by the following equation:

$\% \mathrm{DI}=\left(\mathrm{H}_{\text {serum fraction }} / \mathrm{H}_{\text {ice cream }}\right) * 100$

Where:

$\mathrm{H}_{\text {serum fraction }}=$ height of the whey layer formed $(\mathrm{mL})$;

$\mathrm{H}_{\text {ice cream }}=$ total height of the ice cream $(\mathrm{mL})$.

\subsection{Determination of Calcium (Ca) and Magnesium (Mg)}

The determination of Calcium (Ca) and Magnesium $(\mathrm{Mg})$ in the main ingredients, both liquid and solid, was performed by titration with EDTA (ethylenediamine tetraacetic acid) solution as described in the methodology by Bird et al. (1961).

\subsection{Statistical analysis}

All parameters were performed in triplicate and the results of zeta potential, particle size, rheological behavior, desorption, and $\mathrm{Ca}+\mathrm{Mg}$ concentration were expressed as the mean value \pm standard deviation (SD). One-way ANOVA with post hoc was used to compare data obtained from the application of different dairy wheys and their proportions in the ice creams. The Tukey's HSD test was used when the difference was detected with 95\% confidence $(p<0.05)$. Statistical analyses were performed using Statistica 7.0 software (StatSoft - USA).

\section{Results and discussions}

\subsection{Particle size and Zeta Potential}

The zeta potential of emulsions determines whether the particles tend to coalesce or not, that is, it evaluates constant stability thereof. Along with particle size, zeta potential measurements can be used to predict the stability of ice cream emulsions. According to Achouri et al. (2012) 
and Malvern (2004), a zeta potential with a value (in magnitude) of more than $30 \mathrm{mV}$ indicates the impedance of the droplet aggregation of an emulsion, which in turn, provides the increase of its stability by electrostatic repulsion.

According to table 2, it is observed that the zeta potential increased (it becomes less negative) along with the particle size in a concentration-dependent manner as wheys were added. This behavior indicates that the dairy byproducts do not help to prevent the aggregation of droplets present in the ice cream mixes, meaning that the ice creams mixes containing the smallest quantity of residues were more stable, even though only $21.43 \%$ (6) of the total samples (28) are considered unstable since the threshold between stable and unstable suspensions is usually at $\pm 30 \mathrm{mV}$ (particles with zeta potential greater than $+30 \mathrm{mV}$ or less than $30 \mathrm{mV}$ are normally considered stable) (Malvern, 2004; et al., 2006; Tangsuphoom et al., 2009). In this way, chocolate flavor samples, except for the ice cream mix with $100 \%$ butter whey, were considered to be stable and those with cream flavor formulation of up to $75 \%$ of ricotta whey, $25 \%$ of cheese whey, and $75 \%$ of butter whey, also presented values of zeta potential below $-30 \mathrm{mV}$.

The zeta potential of ice creams mixes developed with $100 \%$ milk (without any residues) was similar to the vanilla-flavored ice cream mix also developed with $100 \%$ milk by Aboulfazli et al. (2014) $(-36.56 \mathrm{mV})$ and Aboulfazli et al. (2015) (-36.56 and $-35.10 \mathrm{mV})$. Regarding other formulations, the same study by Aboulfazli et al. (2014) when evaluating the effect of vegetable milks on the physical and rheological properties of ice cream, found that the formulation with coconut milk was more unstable $(-30.70 \mathrm{mV})$ than soy milk $(-35.50 \mathrm{mV})$ and the majority of samples developed in the present study (66.67\% of samples). The zeta potential variation between the samples was also found in the research by Cheng et al. (2015) (25 to $-50 \mathrm{mV}$ ) when analyzing the effects of milk protein-polysaccharides interactions on the stability of ice cream mix model systems.
Compared to the cow's milk and vegetable milk-based ice creams mixes by Aboulfazli et al. (2014) (810-2541 nm) and Aboulfazli et al. (2015) $(810-8.628 \mathrm{~nm})$, the particle size values of ice cream mixes of the present study were lower (308-755 nm). Furthermore, Whelan et al. (2008) when studying the physicochemical and sensorial optimization of a low glycemic index in ice cream made with cow's milk, also presented high values $(\approx 4,850 \mathrm{~nm})$. For the particle sizes found by Cheng et al. (2015) (610$990 \mathrm{~nm})$ in coconut oil and cow's milk ice creams mixes, only three samples presented sizes greater than $610 \mathrm{~nm}(100 \%$ cream flavored cheese whey, and $100 \%$ cream and chocolateflavored ricotta whey).

The digestive process is affected by a wide variety of factors, including particle size, which is usually related to the surface area available for enzymatic action (Al-Rabadi et al., 2009). Based on this, Blasel et al. (2006) found that the starch access by $\alpha$-amylase significantly decreases for every $100 \mu \mathrm{m}$ increase in grain particle size of milled corn. Regarding the ingestion of breads, de la Hera et al. (2014) when evaluating the effects of flour particle size on gluten-free bread at an in vitro digestibility model, found difficulties in the digestibility of the starch as particle size increased, since the larger the particle size is, the larger is the quantity of low digestible starch and resistant starch.

Therefore, since the smaller the particle size the better the digestibility of a food, the ice creams mixes of the present study were shown to be more digestible, although the particle size increased with the addition of different wheys (those made with ricotta whey had higher sizes than the cheese whey and butter whey ice creams, respectively). 
Table 2. Data of zeta potential, particle size, and desorption index (DI) of ice cream samples.

\begin{tabular}{|c|c|c|c|c|c|c|}
\hline \multirow[t]{2}{*}{ Sample } & \multicolumn{2}{|c|}{$\begin{array}{l}\text { Zeta potential } \\
(\mathrm{mV})\end{array}$} & \multicolumn{2}{|c|}{$\begin{array}{l}\text { Particles size } \\
(\mathbf{n m})\end{array}$} & \multicolumn{2}{|c|}{$\begin{array}{c}\text { Desorption Index (DI) } \\
(\%)\end{array}$} \\
\hline & Cream flavor & Chocolate flavor & Cream flavor & Chocolate flavor & Cream flavor & $\begin{array}{c}\begin{array}{c}\text { Chocolate } \\
\text { flavor }\end{array} \\
\end{array}$ \\
\hline \multicolumn{7}{|l|}{ Ricotta whey } \\
\hline Commercial & $-40.70 \pm 1.01^{\mathrm{a}}$ & $-42.20 \pm 1.47^{a}$ & $334.57 \pm 3.5^{\mathrm{c}}$ & $307.90 \pm 10.69^{\mathrm{e}}$ & $15.00 \pm 1.00^{\mathrm{d}}$ & $3.00 \pm 1.00^{\mathrm{ab}}$ \\
\hline $0 \%$ & $-35.57 \pm 2.05^{b}$ & $-38.53 \pm 1.96^{\mathrm{ab}}$ & $343.27 \pm 10.92^{c}$ & $308.97 \pm 7.05^{\mathrm{e}}$ & $10.00 \pm 2.00^{\mathrm{e}}$ & $2.00 \pm 1.00^{\mathrm{ab}}$ \\
\hline $25 \%$ & $-33.28 \pm 1.33^{\mathrm{bc}}$ & $-36.15 \pm 2.00^{\mathrm{bc}}$ & $346.23 \pm 2.82^{\mathrm{c}}$ & $353.37 \pm 4.04^{\mathrm{d}}$ & $15.00 \pm 1.00^{\mathrm{d}}$ & $1.00 \pm 1.00^{\mathrm{b}}$ \\
\hline $50 \%$ & $-31.00 \pm 0.60^{\mathrm{cd}}$ & $-33.77 \pm 2.22^{\mathrm{c}}$ & $349.20 \pm 7.45^{\mathrm{c}}$ & $397.77 \pm 5.90^{c}$ & $20.00 \pm 0.00^{\mathrm{c}}$ & $1.00 \pm 0.00^{\mathrm{b}}$ \\
\hline $75 \%$ & $-30.22 \pm 0.90^{\mathrm{cd}}$ & $-33.35 \pm 0.76^{\mathrm{c}}$ & $551.88 \pm 15.09^{b}$ & $541.10 \pm 10.99^{b}$ & $30.00 \pm 1.00^{\mathrm{b}}$ & $3.00 \pm 1.00^{\mathrm{ab}}$ \\
\hline $100 \%$ & $-29.43 \pm 1.33^{\mathrm{d}}$ & $-32.93 \pm 0.81^{\mathrm{c}}$ & $754.57 \pm 29.05^{\mathrm{a}}$ & $684.43 \pm 16.65^{a}$ & $39.00 \pm 3.00^{\mathrm{a}}$ & $4.00 \pm 1.00^{\mathrm{a}}$ \\
\hline \multicolumn{7}{|l|}{ Cheese whey } \\
\hline Commercial & $-40.70 \pm 1.01^{\mathrm{a}}$ & $-42.20 \pm 1.47^{a}$ & $334.57 \pm 3.65^{\mathrm{d}}$ & $307.90 \pm 10.69^{d}$ & $15.00 \pm 1.00^{\mathrm{c}}$ & $3.00 \pm 1.00^{\mathrm{a}}$ \\
\hline $0 \%$ & $-35.57 \pm 2.05^{b}$ & $-38.53 \pm 1.96^{\mathrm{b}}$ & $343.27 \pm 10.92^{\mathrm{d}}$ & $308.97 \pm 7.05^{\mathrm{d}}$ & $10.00 \pm 2.00^{\mathrm{d}}$ & $2.00 \pm 1.00^{\mathrm{a}}$ \\
\hline $25 \%$ & $-32.73 \pm 1.11^{b c}$ & $-34.58 \pm 0.98^{c}$ & $376.02 \pm 9.91^{\mathrm{cd}}$ & $340.05 \pm 8.74^{\mathrm{cd}}$ & $13.00 \pm 1.00^{\mathrm{c}}$ & $2.00 \pm 0.00^{\mathrm{a}}$ \\
\hline $50 \%$ & $-29.90 \pm 1.64^{c}$ & $-30.63 \pm 0.67^{\mathrm{d}}$ & $408.77 \pm 9.00^{c}$ & $371.13 \pm 12.60^{c}$ & $15.00 \pm 3.00^{c}$ & $1.00 \pm 0.00^{\mathrm{a}}$ \\
\hline $75 \%$ & $-25.97 \pm 0.78^{d}$ & $-30.38 \pm 0.40^{\mathrm{d}}$ & $566.83 \pm 23.81^{b}$ & $447.12 \pm 13.97^{b}$ & $20.00 \pm 2.00^{\mathrm{b}}$ & $1.00 \pm 1.00^{\mathrm{a}}$ \\
\hline $100 \%$ & $-22.03 \pm 0.49^{\mathrm{e}}$ & $-30.13 \pm 0.45^{\mathrm{d}}$ & $724.90 \pm 39.01^{\mathrm{a}}$ & $523.10 \pm 18.42^{\mathrm{a}}$ & $25.00 \pm 2.00^{\mathrm{a}}$ & $1.00 \pm 0.00^{\mathrm{a}}$ \\
\hline \multicolumn{7}{|l|}{ Butter whey } \\
\hline Commercial & $-40.70 \pm 1.01^{\mathrm{a}}$ & $-42.20 \pm 1.47^{a}$ & $334.57 \pm 3.65^{\mathrm{e}}$ & $307.90 \pm 10.69^{c}$ & $15.00 \pm 1.00^{\mathrm{a}}$ & $3.00 \pm 1.00^{\mathrm{a}}$ \\
\hline $0 \%$ & $-35.57 \pm 2.05^{b}$ & $-38.53 \pm 1.96^{b}$ & $343.27 \pm 10.92^{\mathrm{e}}$ & $308.97 \pm 7.05^{\mathrm{c}}$ & $10.00 \pm 2.00^{\mathrm{b}}$ & $2.00 \pm 1.00^{\mathrm{ab}}$ \\
\hline $25 \%$ & $-34.52 \pm 1.26^{\mathrm{b}}$ & $-35.15 \pm 0.95^{\mathrm{c}}$ & $384.08 \pm 8.76^{\mathrm{d}}$ & $375.05 \pm 11.39^{b}$ & $1.00 \pm 1.00^{\mathrm{d}}$ & $1.00 \pm 0.00^{\mathrm{ab}}$ \\
\hline $50 \%$ & $-33.47 \pm 0.55^{\mathrm{b}}$ & $-31.77 \pm 0.25^{\mathrm{d}}$ & $424.90 \pm 9.26^{c}$ & $441.13 \pm 26.17^{\mathrm{a}}$ & $2.00 \pm 0.00^{\mathrm{cd}}$ & $0.00 \pm 0.00^{\mathrm{b}}$ \\
\hline $75 \%$ & $-30.05 \pm 0.45^{\mathrm{c}}$ & $-30.73 \pm 0.20^{\mathrm{d}}$ & $491.53 \pm 0.96^{\mathrm{b}}$ & $463.90 \pm 19.75^{a}$ & $3.00 \pm 0.00^{\mathrm{cd}}$ & $0.00 \pm 0.00^{\mathrm{b}}$ \\
\hline $100 \%$ & $-29.82 \pm 0.46^{c}$ & $-29.70 \pm 0.53^{d}$ & $558.17 \pm 11.10^{\mathrm{a}}$ & $453.39 \pm 19.48^{a}$ & $4.00 \pm 1.00^{c}$ & $0.00 \pm 0.00^{\mathrm{b}}$ \\
\hline
\end{tabular}

Data are presented as mean values \pm Standard deviation (SD). Mean values followed by the same lowercase letter in the column do not differ between themselves by ANOVA with post hoc Tukey test and 95\% of confidence $(\mathrm{p}<0.05)$. 
Table 3. Rheological parameters of the ice cream obtained by Power Law model (or Ostwald de Waale model).

\begin{tabular}{|c|c|c|c|c|c|c|c|c|}
\hline \multirow[t]{2}{*}{ Sample } & \multicolumn{2}{|c|}{$\begin{array}{l}\text { Apparent Viscosity (mPa.s) } \\
\qquad 50 \mathrm{~s}^{-1}\end{array}$} & \multicolumn{2}{|c|}{$\begin{array}{c}\text { Consistency Index } \\
\text { K }(\mathbf{m P a . s})\end{array}$} & \multicolumn{2}{|c|}{$\begin{array}{c}\text { Flow Behavior Index } \\
\text { (n) }\end{array}$} & \multicolumn{2}{|c|}{$\overline{\mathbf{R}^{2}}$} \\
\hline & Cream & Chocolate & Cream & Chocolate & Cream & Chocolate & Cream & Chocolate \\
\hline \multicolumn{9}{|l|}{ Ricotta whey } \\
\hline Commercial & $122.20 \pm 0.91^{\mathrm{c}}$ & $289.40 \pm 1.54^{\mathrm{c}}$ & $364.99 \pm 2.11^{\mathrm{c}}$ & $913.66 \pm 1.23^{\mathrm{e}}$ & $0.76 \pm 0.007^{\mathrm{a}}$ & $0.72 \pm 0.012^{\mathrm{a}}$ & $0.909 \pm 0.003^{\mathrm{a}}$ & $0.981 \pm 0.002^{\mathrm{a}}$ \\
\hline $0 \%$ & $480.20 \pm 1.05^{\mathrm{a}}$ & $462.70 \pm 0.87^{\mathrm{a}}$ & $1757.80 \pm 3.32^{\mathrm{a}}$ & $2305.60 \pm 2.21^{\mathrm{a}}$ & $0.63 \pm 0.005^{\mathrm{a}}$ & $0.60 \pm 0.009^{\mathrm{a}}$ & $0.972 \pm 0.002^{\mathrm{a}}$ & $0.996 \pm 0.001^{\mathrm{a}}$ \\
\hline $25 \%$ & $274.65 \pm 1.03^{b}$ & $455.85 \pm 1.20^{\mathrm{a}}$ & $957.30 \pm 1.02^{\mathrm{b}}$ & $2117.30 \pm 1.01^{\mathrm{ab}}$ & $0.65 \pm 0.003^{\mathrm{a}}$ & $0.60 \pm 0.007^{\mathrm{a}}$ & $0.983 \pm 0.003^{\mathrm{a}}$ & $0.996 \pm 0.003^{\mathrm{a}}$ \\
\hline $50 \%$ & $49.10 \pm 0.80^{\mathrm{d}}$ & $349.00 \pm 1.01^{\mathrm{b}}$ & $175.65 \pm 2.02^{\mathrm{d}}$ & $1926.50 \pm 1.14^{\mathrm{bc}}$ & $0.74 \pm 0.009^{\mathrm{a}}$ & $0.60 \pm 0.007^{\mathrm{a}}$ & $0.912 \pm 0.003^{\mathrm{a}}$ & $0.989 \pm 0.007^{\mathrm{a}}$ \\
\hline $75 \%$ & $43.10 \pm 1.01^{\mathrm{d}}$ & $289.00 \pm 1.33^{\mathrm{c}}$ & $160.65 \pm 2.42^{\mathrm{d}}$ & $1656.30 \pm 3.01^{\mathrm{cd}}$ & $0.73 \pm 0.005^{\mathrm{a}}$ & $0.61 \pm 0.003^{\mathrm{a}}$ & $0.898 \pm 0.005^{\mathrm{a}}$ & $0.991 \pm 0.003^{\mathrm{a}}$ \\
\hline $100 \%$ & $37.10 \pm 0.93^{\mathrm{d}}$ & $229.00 \pm 1.87^{\mathrm{d}}$ & $144.84 \pm 3.07^{\mathrm{d}}$ & $1389.30 \pm 1.20^{\mathrm{d}}$ & $0.73 \pm 0.010^{\mathrm{a}}$ & $0.63 \pm 0.002^{\mathrm{a}}$ & $0.862 \pm 0.001^{\mathrm{a}}$ & $0.979 \pm 0.005^{\mathrm{a}}$ \\
\hline \multicolumn{9}{|l|}{ Cheese whey } \\
\hline Commercial & $122.20 \pm 0.91^{\mathrm{c}}$ & $289.40 \pm 1.54^{\text {ed }}$ & $364.99 \pm 2.11^{\mathrm{c}}$ & $913.66 \pm 1.23^{b}$ & $0.76 \pm 0.007^{\mathrm{a}}$ & $0.72 \pm 0.012^{\mathrm{a}}$ & $0.909 \pm 0.003^{\mathrm{a}}$ & $0.981 \pm 0.002^{\mathrm{a}}$ \\
\hline $0 \%$ & $480.20 \pm 1.05^{\mathrm{a}}$ & $462.70 \pm 0.87^{\mathrm{a}}$ & $1757.80 \pm 3.32^{\mathrm{a}}$ & $2305.60 \pm 2.21^{\mathrm{a}}$ & $0.63 \pm 0.005^{\mathrm{a}}$ & $0.60 \pm 0.009^{\mathrm{a}}$ & $0.972 \pm 0.002^{\mathrm{a}}$ & $0.996 \pm 0.001^{\mathrm{a}}$ \\
\hline $25 \%$ & $267.75 \pm 0.86^{\mathrm{b}}$ & $398.10 \pm 1.01^{\mathrm{b}}$ & $973.31 \pm 1.27^{\mathrm{b}}$ & $2120.30 \pm 0.92^{\mathrm{a}}$ & $0.65 \pm 0.006^{\mathrm{a}}$ & $0.61 \pm 0.005^{\mathrm{a}}$ & $0.988 \pm 0.001^{\mathrm{a}}$ & $0.993 \pm 0.004^{\mathrm{a}}$ \\
\hline $50 \%$ & $55.30 \pm 0.97^{\mathrm{d}}$ & $393.50 \pm 1.32^{\mathrm{b}}$ & $204.77 \pm 1.01^{\mathrm{d}}$ & $1950.70 \pm 1.34^{\mathrm{a}}$ & $0.73 \pm 0.002^{\mathrm{a}}$ & $0.61 \pm 0.008^{\mathrm{a}}$ & $0.840 \pm 0.002^{\mathrm{a}}$ & $0.987 \pm 0.003^{\mathrm{a}}$ \\
\hline $75 \%$ & $53.55 \pm 1.23^{\mathrm{d}}$ & $324.55 \pm 0.98^{c}$ & $183.63 \pm 2.33^{\mathrm{d}}$ & $1908.00 \pm 1.09^{\mathrm{a}}$ & $0.75 \pm 0.003^{\mathrm{a}}$ & $0.60 \pm 0.004^{\mathrm{a}}$ & $0.847 \pm 0.003^{\mathrm{a}}$ & $0.986 \pm 0.002^{\mathrm{a}}$ \\
\hline $100 \%$ & $51.80 \pm 0.79^{\mathrm{d}}$ & $305.60 \pm 0.89^{\text {cd }}$ & $162.29 \pm 2.02^{\mathrm{d}}$ & $1882.40 \pm 1.11^{\mathrm{a}}$ & $0.77 \pm 0.009^{\mathrm{a}}$ & $0.60 \pm 0.005^{\mathrm{a}}$ & $0.855 \pm 0.002^{\mathrm{a}}$ & $0.987 \pm 0.003^{\mathrm{a}}$ \\
\hline \multicolumn{9}{|l|}{ Butter whey } \\
\hline Commercial & $122.20 \pm 0.91^{\mathrm{c}}$ & $289.40 \pm 1.54^{\mathrm{e}}$ & $364.99 \pm 2.11^{\mathrm{c}}$ & $913.66 \pm 1.23^{\mathrm{c}}$ & $0.76 \pm 0.007^{\mathrm{a}}$ & $0.72 \pm 0.012^{\mathrm{a}}$ & $0.909 \pm 0.003^{\mathrm{a}}$ & $0.981 \pm 0.002^{\mathrm{a}}$ \\
\hline $0 \%$ & $480.20 \pm 1.05^{\mathrm{a}}$ & $462.70 \pm 0.87^{\mathrm{a}}$ & $1757.80 \pm 3.32^{\mathrm{a}}$ & $2305.60 \pm 2.21^{\mathrm{a}}$ & $0.63 \pm 0.005^{\mathrm{a}}$ & $0.60 \pm 0.009^{\mathrm{a}}$ & $0.972 \pm 0.002^{\mathrm{a}}$ & $0.996 \pm 0.001^{\mathrm{a}}$ \\
\hline $25 \%$ & $272.30 \pm 0.97^{\mathrm{b}}$ & $433.55 \pm 0.91^{b}$ & $1008.80 \pm 3.03^{b}$ & $2267.00 \pm 2.12^{\mathrm{ab}}$ & $0.65 \pm 0.009^{\mathrm{a}}$ & $0.60 \pm 0.002^{\mathrm{a}}$ & $0.992 \pm 0.004^{\mathrm{a}}$ & $0.994 \pm 0.006^{\mathrm{a}}$ \\
\hline $50 \%$ & $74.40 \pm 0.85^{\mathrm{d}}$ & $404.40 \pm 1.27^{\mathrm{c}}$ & $275.95 \pm 2.01^{\mathrm{cd}}$ & $2228.20 \pm 1.01^{\mathrm{b}}$ & $0.72 \pm 0.007^{\mathrm{a}}$ & $0.60 \pm 0.007^{\mathrm{a}}$ & $0.819 \pm 0.007^{\mathrm{a}}$ & $0.990 \pm 0.003^{\mathrm{a}}$ \\
\hline $75 \%$ & $69.30 \pm 1.17^{\mathrm{d}}$ & $386.65 \pm 1.85^{\mathrm{cd}}$ & $239.43 \pm 2.01^{\mathrm{d}}$ & $2131.00 \pm 1.23^{\mathrm{b}}$ & $0.74 \pm 0.004^{\mathrm{a}}$ & $0.60 \pm 0.005^{\mathrm{a}}$ & $0.837 \pm 0.001^{\mathrm{a}}$ & $0.989 \pm 0.003^{\mathrm{a}}$ \\
\hline $100 \%$ & $64.20 \pm 1.69^{\mathrm{d}}$ & $368.90 \pm 1.03^{\mathrm{d}}$ & $201.83 \pm 3.23^{\mathrm{d}}$ & $2029.10 \pm 2.01^{\mathrm{b}}$ & $0.76 \pm 0.010^{\mathrm{a}}$ & $0.60 \pm 0.009^{\mathrm{a}}$ & $0.862 \pm 0.005^{\mathrm{a}}$ & $0.985 \pm 0.001^{\mathrm{a}}$ \\
\hline
\end{tabular}

Data are presented as mean values \pm standard deviation (SD). Mean values followed by the same lowercase letter in the column do not differ between themselves by ANOVA with post hoc Tukey test and 95\% confidence $(\mathrm{p}<0.05)$. 


\subsection{Rheological behavior}

The effect of melted ice cream type (chocolate or cream) and the concentration of dairy whey products (ricotta whey, cheese whey, and butter whey) in the viscosity is shown in Table 3 and Figures 1, 2, and 3. As one can observe, all samples demonstrated pseudoplastic behavior, meaning that apparent viscosity is a function of the imposed shear rate and it decreases as the shear rate increases. The viscosity reduction may be attributed to structural changes occurring during the shearing process: the emulsified particles tend to decrease in size and to orient themselves towards the flow, which has an impact on the viscosity values (Rossa et al., 2012).

By the information exposed in Table 3, there is a reduction on apparent viscosity as the whey content increases. This fact is attributed to the lower stability for melted ice creams with high whey content, which reflects in the increase of desorption index (Table 4 and Figure 4) and the reduction of zeta potential (Chiewchan et al., 2006).

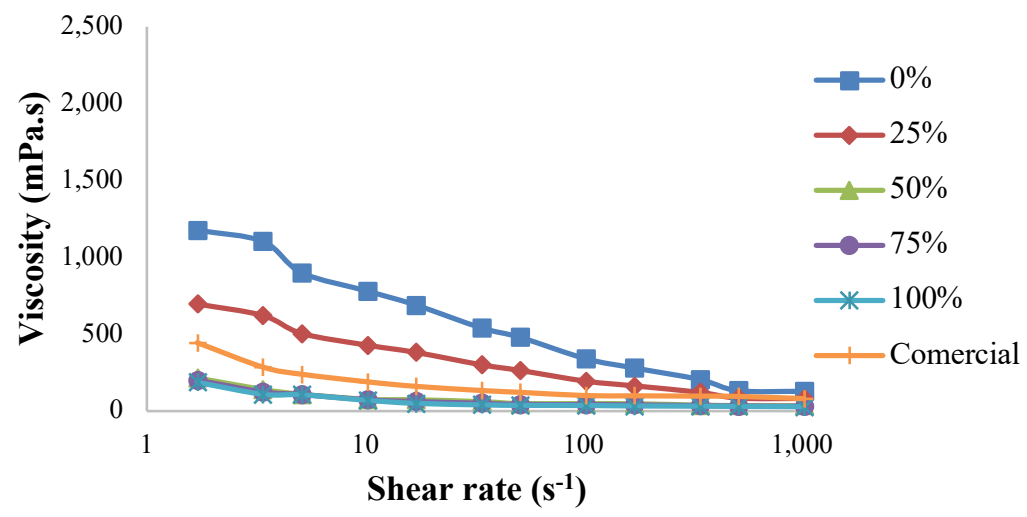

(a)

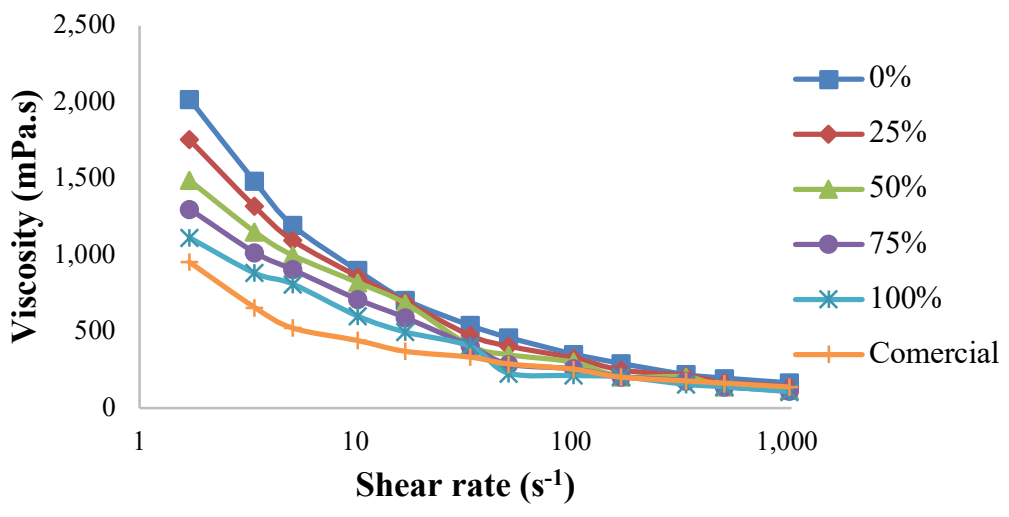

(b)

Figure 1. Effect of shear rate on apparent viscosity of cream (a) and chocolate (b) ice creams made with ricotta whey. 


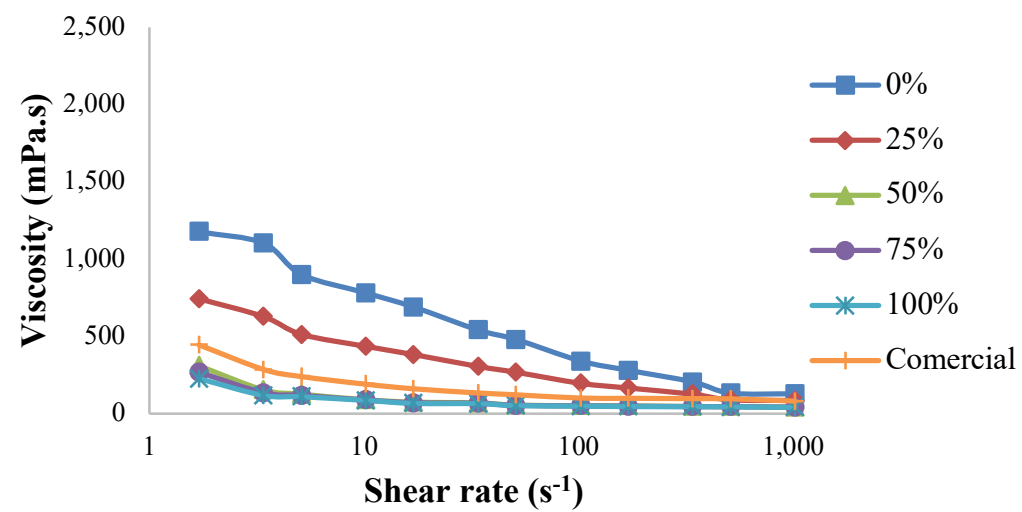

(a)

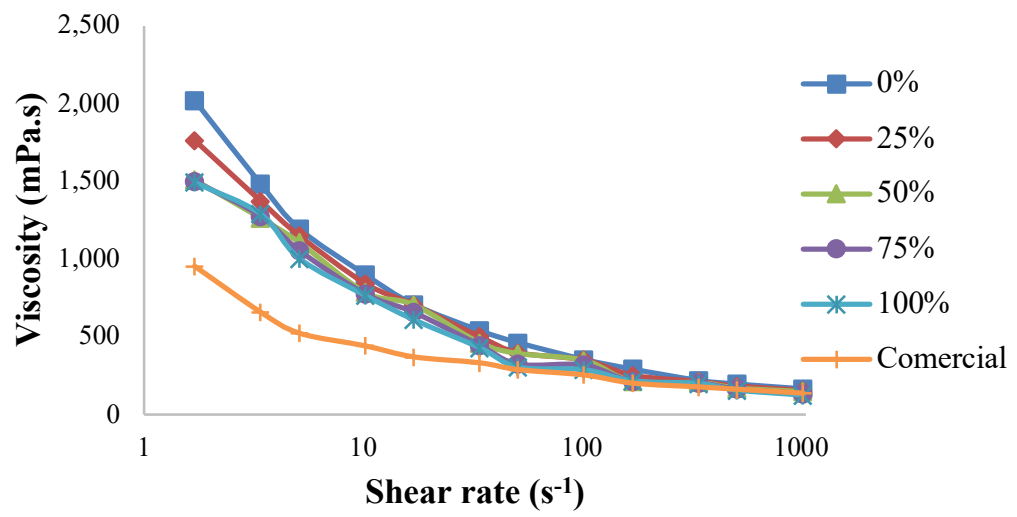

(b)

Figure 2. Effect of shear rate on apparent viscosity of cream (a) and chocolate (b) ice creams made with cheese whey.

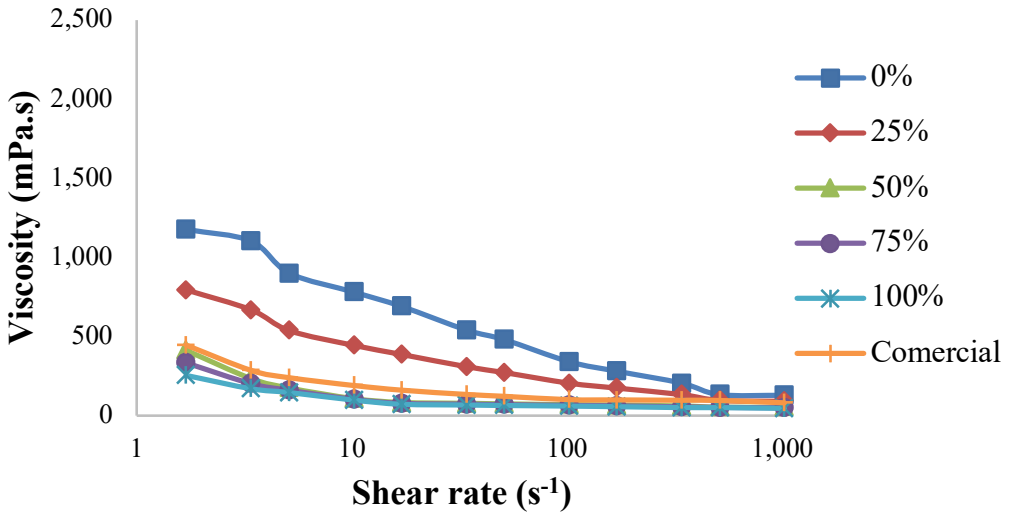

(a) 


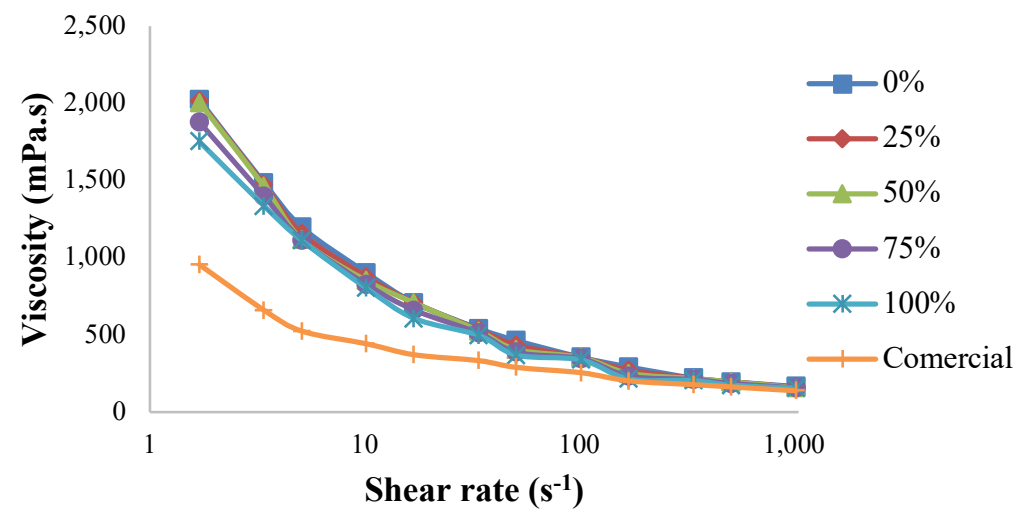

(b)

Figure 3. Effect of shear rate on apparent viscosity of cream (a) and chocolate (b) ice creams made with butter whey.

The highest apparent viscosity values were obtained from butter whey, followed by cheese whey and ricotta whey, irrespective to the melted ice cream type. The qualitative behavior between the commercial melted ice cream brand assessed (which has great acceptance in the Brazilian market) and the formulated melted ice creams is evident as whey products are added to the samples.

For the same whey product, chocolate samples exhibited higher apparent viscosity values compared to the cream samples, which is reflected by the higher parameter $K$ (consistency index, Table 3). This constant was calculated through viscosity data fit from power-law model (also known as Ostwald de Waale model). Besides, the pseudoplastic behavior is more pronounced for chocolate melted ice creams, reflected in the low values of parameter $n$ (flow behavior index) when compared to the cream flavor. It is likely that this result was influenced by the presence of cocoa powder that is obtained from the cocoa paste prepared with seeds that underwent fermentation, drying, roasting, grinding and pressing for the separation of cocoa butter (Medeiros et al., 2009). Precisely because it is devoid of cocoa butter (which according to Gao et al., 2015 causes viscosity reduction), cocoa powder can cause the inverse effect.

At $20 \mathrm{~s}^{-1}$ all samples (except 0 and 25\% ricotta whey) presented lower apparent viscosity than those developed with cow's milk (294 mPa.s), coconut milk (287 mPa.s), and soy milk $(1,012 \mathrm{mPa} . \mathrm{s})$ as seen in the study of Aboulfazli et al. (2015). In the present investigation, the values varied in a relatively large range for both flavors: chocolate (371.4 mPa.s, commercial sample to $708.8 \mathrm{mPa} . \mathrm{s}, 100 \%$ milk) and cream (50.2 mPa.s, $100 \%$ ricotta whey to $690.1 \mathrm{mPa} . \mathrm{s}$, $100 \%$ milk).

Choi et al. (2014) obtained apparent viscosity values at $340.5 \mathrm{~s}-1$ for the vanilla melted ice cream investigated, ranging from 26.3 to $198.9 \mathrm{mPa}$.s. In this study, this property ranged from $155.4 \mathrm{mPa} . \mathrm{s}$ ( $100 \%$ ricotta whey) to $219.7 \mathrm{mPa} . \mathrm{s}$ (100\% milk) for chocolate melted ice cream and $32.2 \mathrm{mPa} . \mathrm{s}$ (100\% ricotta whey) to $135.2 \mathrm{mPa} . \mathrm{s}(100 \%$ milk) for the cream melted ice cream. At $50 \mathrm{~s}^{-1}$, Li et al. (2015) had samples varying from 100 to $430 \mathrm{mPa}$.s. At this same shear rate our results ranged from 289.4 $\mathrm{mPa} . \mathrm{s}$ (commercial sample) to $462.7 \mathrm{mPa} . \mathrm{s}$ (100\% milk) for chocolate type and $37.1 \mathrm{mPa} . \mathrm{s}$ $(100 \%$ ricotta whey) to $480.2 \mathrm{mPa} . \mathrm{s}(100 \%$ milk) for the cream type.

The average apparent viscosity for the melted ice creams assessed by Whelan et al. (2008) at $30 \mathrm{~s}^{-1}$ was $51.5 \mathrm{mPa}$.s. On the other hand, in this investigation the apparent viscosity of chocolate melted ice cream ranged from $333.2 \mathrm{mPa} . \mathrm{s}$ (commercial sample) to 540.8 $\mathrm{mPa} . \mathrm{s}(100 \%$ milk), whereas the cream samples 
ranged from $40.5 \mathrm{mPa} . \mathrm{s}$ (100\% ricotta whey) to $540.9 \mathrm{mPa}$.s, i.e., a much broader range.

In Figures 1, 2 and 3, it is clear the viscosity convergence of all samples to relatively low values $(\sim 100 \mathrm{mPa} . \mathrm{s})$ as the shear rate is increased to $\sim 1,000 \mathrm{~s}^{-1}$. This fact is likely to be connected to the structural breakage of the melted ice cream proteins network due to shear imposed, as emphasized by Rossa et al. (2012).

Considering the high values for the linear correlation coefficient $\left(\mathrm{R}^{2}\right)$ presented in Table 3, it is possible to attest that power-law model provided good adjustment parameters, since $72 \%$ of the samples exhibited $\mathrm{R}^{2}>0.90$. Thus, the rheological behavior of the samples can be satisfactorily described by this model.

\subsection{Stability analysis}

Besides a palatable taste, it is expected from a good ice cream to have moderate melt resistance in the form of uniform homogeneous liquid and the appearance of the original blend (without phase separation), exhibiting a natural color and particles regularly distributed as long as a certain consistency is also maintained when the ice crystals melt. The heterogeneity can be identified by the presence of clots, slag, large, varied size air bubbles, and/or phase separation (Bodyfelt et al., 1988, Marshall, 2003).

Due to the fact that emulsions are thermodynamically unstable, they are susceptible to coalescing interactions immediately after production or during storage. For this reason, this effect was investigated in the present study by measuring the total whey content (Table 2) at different time intervals, from one to seven days after preparation (Figures 4, 5 and 6).

Generally, the samples with ricotta whey desorbed more than the samples with cheese whey and butter whey, respectively.

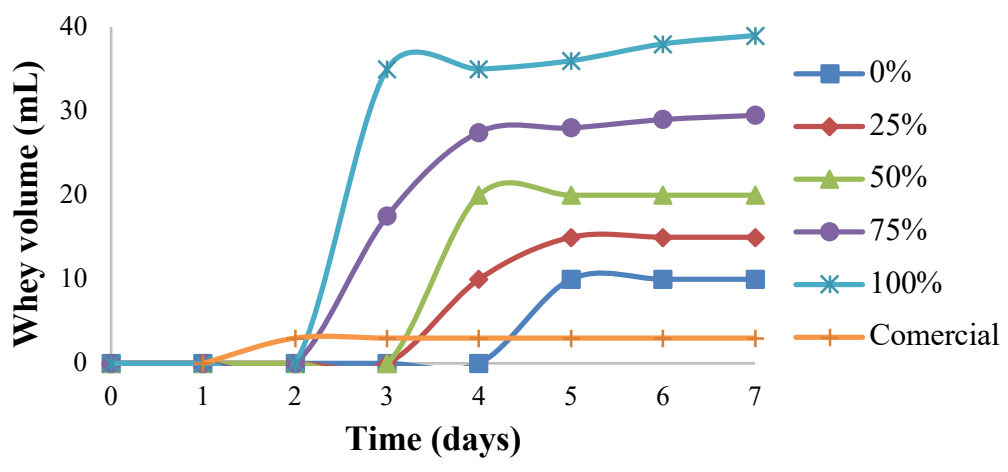

(a)

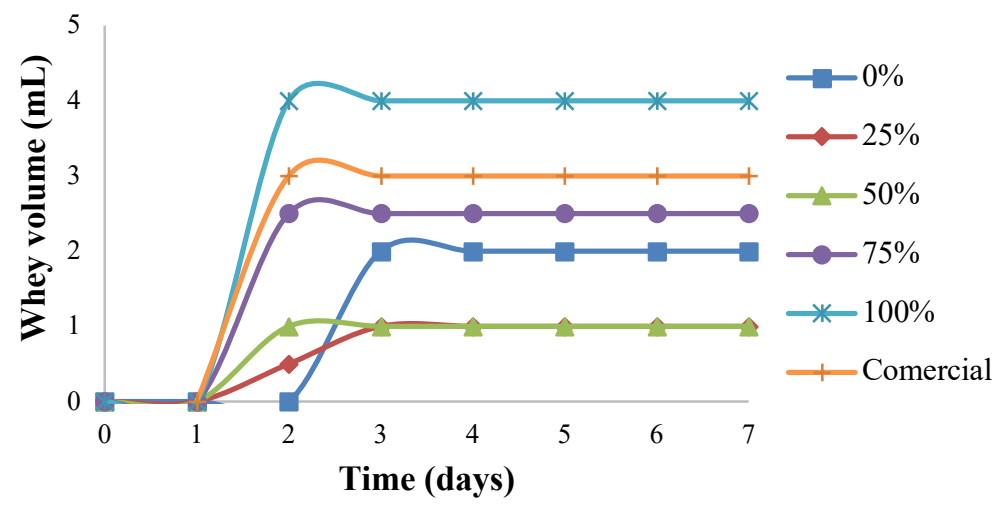

(b)

Figure 4. Effect of ricotta whey concentration in the desorption of cream (a) and chocolate (b) flavor ice cream. 


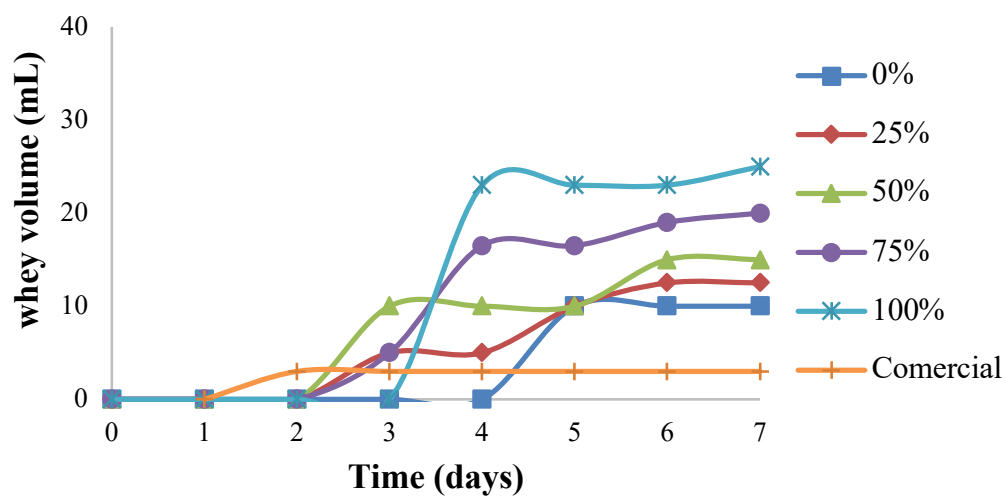

(a)

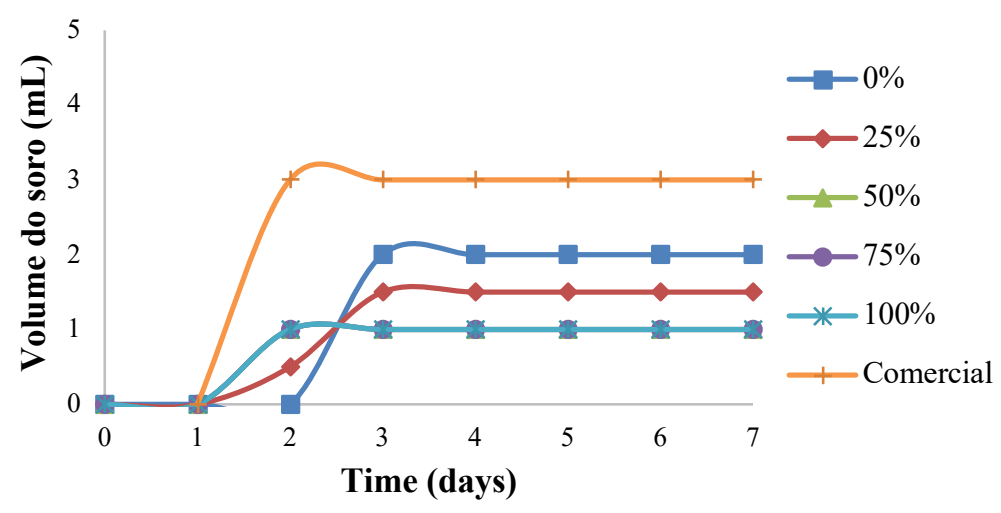

(b)

Figure 5. Effect of cheese whey concentration in the desorption of cream (a) and chocolate (b) flavor ice cream.

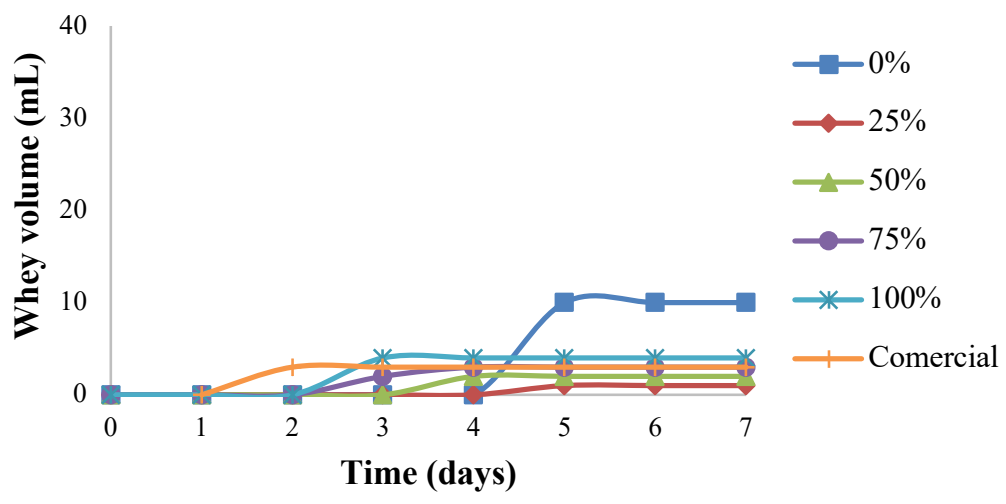

(a) 


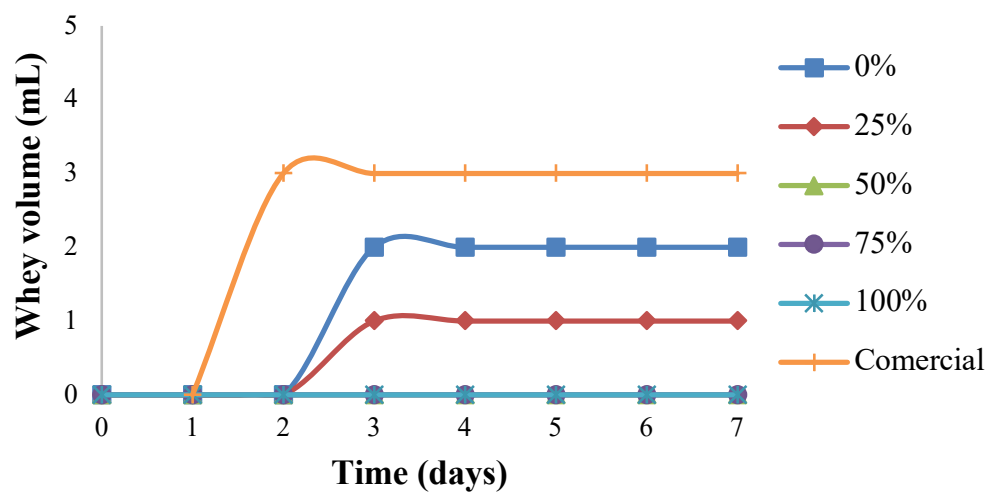

(b)

Figure 6. Effect of butter whey concentration in the desorption of cream (a) and chocolate (b) flavor ice cream.

Taking into consideration the chocolate flavored ice creams, only the $100 \%$ ricotta whey sample desorbed more than the $0 \%$ commercial samples. Besides the type and amount of flavorings, the greater presence of liquid ingredients in the cream flavored ice cream formulations $(66.86 \%$ versus $55.14 \%$ in the chocolate flavor - Table 1) promoted a different behavior, which was the large whey formation right in the early days for most of these ice creams. Samples with butter whey had the lowest D and only the samples with $25 \%$ ricotta whey, and 25 and $50 \%$ cheese whey behaved similarly to the $0 \%$ commercial samples.

Thus, according to the results above, chocolate ice creams show a remarkably superior macroscopic stability than the cream flavor ice cream, regardless of the type of whey added.

\subsection{Determination of Calcium (Ca) and Magnesium (Mg)}

According to Chen et al. (2011), there are three factors that regulate the stability of an emulsion: particle size, particle flocculation and particle distribution between the different phases. In this context, calcium and magnesium ions can destabilize an emulsion, causing precipitation and compromising foaming (Ramkumar et al., 2000).

Figure 7 shows the $\mathrm{Ca}+\mathrm{Mg}$ concentration in the main liquid and solid ingredients used in the formulations. Among the liquid ingredients, milk had the highest concentration of $\mathrm{Ca}$ and $\mathrm{Mg}$, followed by butter whey, cheese whey and ricotta whey, respectively. In contrast, presenting an unexpected behavior, the samples developed with butter whey desorbed less, showed smaller particle sizes and were more stable (Table 2) compared to the samples with cheese whey and ricotta whey. In addition, even the milk-based sample with higher zeta potential and smaller particle size, presented low DI among the samples. This demonstrates the great complexity of the characterization of these materials in terms of their stability, because the parameters are often conflicting between different samples (either favoring or disfavoring the stability).

Regarding the solid ingredients, powdered cocoa was 14.28 times higher in $\mathrm{Ca}+\mathrm{Mg}$ content when compared to the cream flavoring powder, however, it did not negatively influence the stability of the ice creams since they were more stable (higher zeta potential, lower particle size, and lower desorption). This fact may be associated with the small percentage of these flavorings in the ice cream formulations $(2.91 \%$ cream flavor versus $11.63 \%$ cocoa powder Table 1) when compared to the liquid ingredients $(66.86 \%$ for cream flavor versus $55.14 \%$ for the chocolate flavor - Table 1). 
Other authors found similar results with that of the present study for $\mathrm{Ca}+\mathrm{Mg}$ in cow's milk: Visentin et al. (2018) (150.52 mg / $100 \mathrm{~mL})$, Franzoi et al. (2018) (123.35 mg / $100 \mathrm{~mL})$, Martino et al. (2011) (102.00 mg/ $100 \mathrm{~mL})$, and Yildiz et al. (2005) (116.05 mg / $100 \mathrm{~mL}$ ). Taking into consideration the different influences on food composition, Jensen et al. (2012) when analyzing the composition of

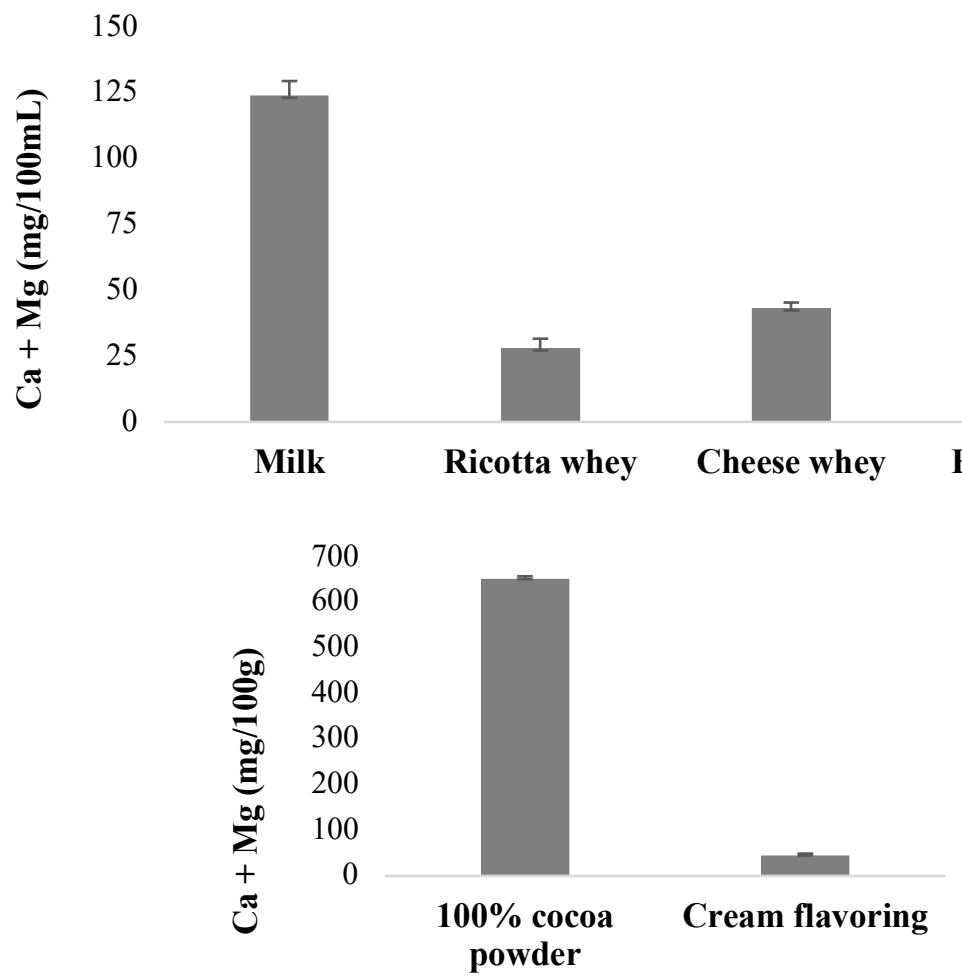

cow's milk from different breeds, showed that $\mathrm{Ca}+\mathrm{Mg}$ content varied between Jersey (158.59 $\mathrm{mg} / 100 \mathrm{~mL}$ ) and Holstein-Friesian breed (122.55 mg / $100 \mathrm{~mL})$. Haug et al. (2007) pointed out that the milk composition of cows varies in different regions of Norway: north $(137.00 \mathrm{mg} / 100 \mathrm{ml})$, south $(133.90 \mathrm{mg} / 100$ $\mathrm{ml})$, east $(131.90 \mathrm{mg} / 100 \mathrm{ml})$, and west 132.70 $\mathrm{mg} / 100 \mathrm{~mL})$.

(b)

Figure 7. Content of Calcium and Magnesium in the main liquid (a) and solid (b) ingredients of ice cream. Data are presented as mean values \pm standard deviation.

The content of $\mathrm{Ca}+\mathrm{Mg}$ for cheese whey of the present research was lower, but similar to the one found by Martino et al. (54.80 mg / $100 \mathrm{~mL})$, despite Franzoi et al. (2018) founding a lower content $(28.87 \mathrm{mg} / 100 \mathrm{~mL})$. It should be noted that this variation occurs naturally and is mainly associated with the type of cheese from which the whey originates (Kandarakis, 1986).

\section{Conclusions}

The results showed that the high contents of ricotta whey (100\% cream flavor), cheese whey (50\% cream flavor), and butter whey $(100 \%$ cream and chocolate flavor) had zeta potential values between +30 and $-30 \mathrm{mV}$, which compromises the stability of ice creams.

Regarding the rheological behavior, all samples showed predominant pseudoplastic character, with prevalence of the samples of chocolate over those of cream flavor. However, under high shear rates $\left(\sim 1000 \mathrm{~s}^{-1}\right)$, the apparent viscosity values converge to a Newtonian plateau of approximately $100 \mathrm{mPa} . \mathrm{s}$

In the chocolate ice creams, practically no phase separation was observed, except in those developed with 75 and $100 \%$ of ricotta whey, that is, significant amounts of whey. In contrast, cream flavor samples, as indicated by their zeta 
potential values, were more unstable and the phase separation occurred more quickly and intensely, evidencing the influence of the type of ice cream flavor on its stability, particle size, rheology, and desorption.

$\mathrm{Ca}+\mathrm{Mg}$ content of the main ingredients used was not a strong and decisive factor in the destabilization of the samples. Although the wheys had lower concentrations of these minerals in comparison to milk, as well as the flavoring of cream in relation to the cocoa powder, they did not prevent or delay the phases separation of the ice cream for up to a week.

Thus, ricotta whey (up to $25 \%$ ), cheese whey (up to $50 \%$ ) and butter whey (up to $75 \%$ ) were promising candidates for the production of ice cream. In addition, taking into consideration the difficulty of analyzing the stability and performance factors evaluated here, the present study indicates the importance thereof and suggests that other quality parameters should be also analyzed in order to clarify the influence of these wheys on the characteristics of ice cream.

\section{References}

Aboulfazli, F., Baba, A. S. \& Misran, M. (2014). Effect of Vegetable Milks on the Physical and Rheological Properties of Ice Cream. Food Science and Technology Research, 20(5), 987-996.

Aboulfazli, F., Baba, A. S. \& Misran, M. (2015). Effects of fermentation by Bifidobacterium bifidum on the rheology and physical properties of ice cream mixes made with cow and vegetable milks. International Journal of Food Science and Technology, 50, 942-949.

Achouri, A., Zamani, Y., \& Boye, J. I. (2012).

Stability and Physical Properties of Emulsions Prepared with and without Soy Proteins. Journal of Food Research., (1)1, 254-267.

Akesowan, A. (2009). Influence of soy protein isolate on physical and sensory properties of ice cream. Thai Journal of Agricultural Science, 42, 1-6.
Al-Rabadi, G. J. S., Gilbert, R. G., \& Gidley, M. J. (2009). Effect of particle size on kinetics of starch digestion in milled barley and sorghum grains by porcine alpha-amylase. Journal of Cereal Science, 50, 198-204.

BahramParvar, M., Razavi, S. M. A., \& Khodaparast, M. H. H. (2010). Rheological characterization and sensory evaluation of a typical soft ice cream made with selected food hydrocolloids. Food Science and Technology International, 16(1), 79-88.

Bird, E. W., Weber, J., Cox, C. P. \& Chen, T. C. (1961). Determination of Calcium and Magnesium in Milk by E.D.T.A. Titration. Journal of Dairy Science, 44(6), 1036-1046.

Blasel, H. M., Hoffman, P. C., \& Shaver, R. D. (2006). Degree of starch access: an enzymatic method to determine starch degradation potential of corn grain and corn silage. Animal Feed Science and Technology, 128, 96-107.

Bodyfelt, F. W., Tobias, J., \& Trout, G. M. (1988). Sensory evaluation of ice cream and related products (166-226). In: The sensory evaluation of dairy products (3rd ed.). New York: Library of Congress Cataloging-inPublication Data.

Bourne, M. C. (2002). Physics and texture. In Bourne, M. C., Food texture and viscosity: Concept and measurement (Chapther 3, pp.59-106). Harcourt Place: Academic Press.

Božanić, R., Barukčić, I., Jakopović, K. L. \& Tratnik, L. (2014). Possibilities of whey utilisation. Austin journal of nutrition and food sciences, 2(7), 1036.

Chen, J., Vogel, R., Heinrich, G., Clausse, D. \& Dutschk, V. (2011). Influence of the Particle Type on the Rheological behavior of Pickering Emulsion. Colloids and Surfaces A: Physicochemical and Engineering Aspects, 382(1), 238-245.

Cheng, J., Ma, Y., Li, X., Yan, T. \& Cui, J. (2015). Effects of milk proteinpolysaccharide interactions on the stability of ice cream mix model systems. Food Hydrocolloids, 45, 327-336. 
Chiewchan, N., Phungamngoen, C., \& Siriwattanayothin, S. (2006). Effect of homogenizing pressure and sterilizing condition on quality of canned high fat coconut milk. Journal of Food Engineering, 73, 38-44.

Choi, M. J. \& Shin, K. S. (2014), Studies on Physical and Sensory Properties of Premium Vanilla Ice Cream Distributed in Korean Market. Korean Journal for Food Science of Animal Resources, 34(6), 757-762.

Corredig, M., Sharafbafi, N., \& Kristo, E. (2011). Polysaccharide-protein interactions in dairy matrices, control and design of structures. Food Hydrocolloids, 25(8), 1833-1841.

de la Hera, E., Rosell, C. M., \& Gomez, M. (2014). Effect of water content and flour particle size on gluten-free bread quality and digestibility. Food Chemistry, 151, 526-531.

Franzoi, M., Niero, G., Penasa, M., Cassandro, M. \& De Marchi, M. (2018). Technical note: Development and validation of a new method for the quantification of soluble and micellar calcium, magnesium, and potassium in milk. Journal of Dairy Science, 101, 1883-1888.

Gao, X., Guo, T., Han, F., Tian, Y. \& Zhang, V. (2015). Rheological and Sensory Properties of Four Kinds of Dark Chocolates index ice cream formulation. American Journal of Analytical Chemistry, 6, 1010-1018.

Haug, A., Steinnes, E., Harstad, O. M., Prestløkken, E., Schei, I. \& Salbu, B. (2015). Trace elements in bovine milk from different regions in Norway. Acta Agriculturae Scandinavica, Section A, 65(2), 85-96.

Janczukowicz, W., Zieliński, M. \& Debowski, M. (2008). Biodegradability evaluation of dairy effluents originated in selected sections of dairy production. Bioresource Technology, 99, 4199-4205.

Jensen, H. B., Poulsen, N. A., Andersen, K. K., Hammershøj, M., Poulsen, H. D. \& Larsen, L. B. (2012). Distinct composition of bovine milk from Jersey and Holstein-Friesian cows with good, poor, or noncoagulation properties as reflected in protein genetic variants and isoforms. Journal of Dairy Science, 95, 6905-6917.

Kandarakis, G. J. (1986). Traditional whey cheeses. Ewe's \& Goat Milk and Milk products, Bulletin of the IDF, 202, 118-124. Brussels, Belgium, International Dairy Federation.

Kumar, D. D., Mann, B., Pothuraju, R., Sharma, R., Bajajb, R. \& Minaxia. (2016). Formulation and characterization of nanoencapsulated curcumin using sodium caseinate and its incorporation in ice cream. Food \& Function, 7, 417-424.

Li, L., Kim, J., Jo, Y., Min, S., \& Chun, J. (2015). Effect of Porcine Collagen Peptides on the Rheological and Sensory Properties of Ice Cream. Korean Journal for Food Science of Animal Resources, 35, 156-163.

Liang, B. \& Harte, R. W. (2004). Effects of Milk Powders in Milk Chocolate. Journal of Dairy Science. 87, 20-31.

Makarem, N., Scott, M., Quatromoni, P., Jacques, P. \& Parekh, N. (2014). Trends in dietary carbohydrate consumption from 1991 to 2008 in the framingham heart study offspring cohort. British Journal of Nutrition, 111(11), 2010-2023.

Malvern. (2004). Zetasizer Nano Series User Manual. Worcestershire, England.

Marshall, R. T., Goff, H. D. \& Hartel, R. W. (2003). Ice Cream (6rd ed.). New York: Kluwer Academic/Plenum Publishers.

Martino, F. A. R., Sánchez, M. L. F. \& SanzMedel, A. (2001). The potential of double focusing-ICP-MS for studying elemental distribution patterns in whole milk, skimmed milk and milk whey of different milks. Analytica Chimica Acta, 442, 191200.

Medeiros. M. L. \& Lannes, S. C. S. (2009). Avaliação química de substitutos de cacau e estudo sensorial de achocolatados formulados. Ciência e Tecnologia de Alimentos, 29(2), 247-253. 
Onsaard, E., Vittayanont, M., Srigam, S., \& McClements, D. J. (2006). Comparison of properties of oil-in-water emulsions stabilized by coconut cream proteins with those stabilized by whey protein isolate. Food Research International, 39, 78-86.

Ramkumar, C., Singh, H., Munro, P. A. \& Singh, A. M. (2000). Influence of Calcium, Magnesium, or Potassium Ions on the Formation and Stability of Emulsions Prepared Using Highly Hydrolyzed Whey Proteins. Journal of Agricultural and Food Chemistry, 48, 1598-1604.

Rivas, J., Prazeres, A. R., Carvalho, F. \& Beltrán, F. (2010). Treatment of cheese whey wastewater: combined coagulationflocculation and aerobic biodegradation. Journal of Agricultural and Food Chemistry, 58(13), 7871-7877.

Rossa, P. N., Burin, V. M. \& Bordignon-Luiz, M. T. (2012). Effect of microbial transglutaminase on functional and rheological properties of ice cream with different fat contents. LWT - Food Science and Technology, 48, 224-230.

Sansonetti, S., Curcio, S., Calabrò, V. \& Iorio, G. (2009). Bio-ethanol production by fermentation of ricotta cheese whey as an effective alternative non-vegetable source. Biomass \& Bioenergy, 33(12), 1687-1692.

Silva, D. G. P. (2011). Resíduos na Indústria de Alimentos. Série Sistema de Gestão Ambiental. Viçosa: Editora UFV.

Singh, A. K. \& Singh, K. (2012). Utilization of whey for the production of instant energy beverage by using response surface methodology. Advance Journal of Food Science and Technology, 4, 103-111.

Tangsuphoom, N. \& Coupland, J. N. (2009). Effect of thermal treatments on the properties of coconut milk emulsions prepared with surface-active stabilizers. Food Hydrocolloids, 23, 1792-1800.

Tharp, B. W., Forrest, B., Swan, C., Dunning, L. \& Hilmoe, M. (1998). Basic factors affecting ice cream meltdown. In: Ice Cream (Buchheim, W., ed). Proceedings of the
International Symposium held in Athens, Greece. Belgium: International Dairy Federation.

Vadiveloo, M., Scott, M., Quatromoni, P., Jacques, P. \& Parekh, N. (2014), Trends in dietary fat and high-fat food intakes from 1991 to 2008 in the framingham heart study participants. British Journal of Nutrition, 111(4), 724-734.

Visentin, G., Penasa, M., Niero, G., Cassandro, M. \& De Marchi, M. (2018). Phenotypic characterisation of major mineral composition predicted by mid-infrared spectroscopy in cow milk. Italian Journal of Animal Science, 17(3), 549-556.

Walstra, P. \& Jonkman, M. (1998). Emulsion and foam stabilization. In Buchheim, W. (Ed.), Ice Cream, International Dairy Federation, Brussels, Belgium.

Whelan, A. P., Vega, C., Kerry, J. P. \& Goff, H. D. (2008). Physicochemical and sensory optimisation of a low glycemic index ice cream formulation. International Journal of Food Science and Technology, 43, 15201527.

Yildiz, H. \& Kaygusuzoğlu, E. (2005). Investigation of $\mathrm{Ca}, \mathrm{Zn}, \mathrm{Mg}, \mathrm{Fe}$ and $\mathrm{Cu}$ concentrations in blood and milk of cows with negative and positive CMT results. Bulletin of the Veterinary Institute in Pulawy, 49, 209-213.

\section{Acknowledgment}

The Federal University of Bahia (UFBA) and the Federal University of Rio de Janeiro (UFRJ) are grateful to the authors of this study for providing the necessary infrastructure for the development of this work. We also thank the Federal Institute of Alagoas (IFAL), especially the Satuba campus since it was the donor of the dairy by-products. 